\title{
Challenges to Create a Global Cohesive Society in Post-Conflict Situations and Its Impact in Federal Democratic Republic Of Nepal
}

\author{
Bishnu Hari Nepal, PhD \\ Visiting Professor of International Relations, \\ Peace, Conflict, Security and Development Studies, TU \\ Email: bhnfsr@gmail.com
}

\begin{abstract}
After Cold War, "Clashes of Civilizations" could be paramount in the coming centuries. Naturally, they will be supported by the detrimental effects of technology like the Artificial Intelligence (AI) further advanced in the 21st century in the process of the evolution of a global cohesive society. Even the space will be a playground of the mundane strategic order. Countries like Federal Democratic Republic of Nepal can play a crucial role reviving her glory of the dawn of civilization on earth as a soft-power resulted from the geo-political and strategic values utilizing modalities recommended by the author.
\end{abstract}

Key Words: Global cohesive society, Himalayan world order, Post-conflict situations, new world order, Federal Democratic Republic of Nepal

\section{Introduction}

Even though the Himalayan Mountain System is recognized as the youngest-mountain-system of the world, but it propounded Two Great Civilizations on the planet-earth. The Two Great Civilizations are the Hinduism and the Buddhism (Thapa, 2010). They stand not only as religions, but also as philosophies guided by their visions and thoughts for a better way of life to the contemporary world tending but failed to make a cohesive society at large. The evolution of Sanskrit language and its literature like Vedas (Rig-Veda, Sama Veda, Yajur Veda and Atharva Veda), Puranas (18), Upanishads, Smriti Granthas, Shrimad Bhagawat Gita (Adhikari, 2057), Mahabharata (Vedvyas), Ramayana (Balmikiya Ramayana), Ratnawali ( Nagarjunra Unko Shunnyawaad), Nepal Mahatmya, Swasthani (Subedi, 2063), etc. are unmatched creations of that age. For instance, the origin of the German language is Sanskrit, and it is known as Indo-Germanic. Due to Indian scholars of that time it has been Indo-Germanic but it should be Sanskrito-Germanic in reality. In fact, no book has been possible so far like epic Mahabharata with 100000 stanzas. This author ponders: is this not a "World Order" for a cohesive society?

Pertinent question stands: is there no need of the "Third Term" or "Pole" besides what today's School of Thought of International Relations until post-Modern Theories, for instance, by Francis Fukuyama at "The End of the History and the Last Man" and Samuel P. Huntington's "The Clash of Civilizations", and others later, categorically stand on only at "Hard Power" and "Soft Power" and "uni-multi-polar world" for a cohesive society? Here is the challenge of omission of the "Power of Enlightenment" for a cohesive society.

The great researcher of Nepal of our times, Yogi Narahari Nath in his book "Aitihasik Shikharini Yaatraa" quotes from his naraharisangrahat (Nath, 2049) as astyuttarasyaamdishidevataatmaahimaalayonaamanaagaadhiraajah.- meaning-to the north of Bharatbarsha, as abode of Gods and the earth's majestic Himalayas (maanadandah), full of resources including water -the Kingdom of the Himalayas exists. As a matter of fact, in terms of modern "Soft Power" also, Nepal is a "Water Power" of the world. In 2013, UNESCO, from Nepal, on Ayurveda, 


\section{7 | Journal of APF Command and Staff College}

preserved two oldest scripts on earth written in Sanskrit/Pali languages. Basically, the rich resources of Nepal Himalayas like bhaassyantiratnaanimahaushadhischa (Ibid) -for instance- Laxmana Sanjivani (Ibid) are well recognized in Ramayana. It helped crucially for a sound and healthy cohesive society in a multi-dimensional perspective.

One book in two forms "Himalaya Kah Rahaa Hai" (Adwait, 2013), Part I and II, give the details of the wonders of the Nepal Himalayas containing resources and creations from the caves. Some of the settlements and caves are recently explored by UNESCO (UNESCO, 2013) and other archaeological institutes from Japan, UK, USA and Germany in Lumbini and Mustang. The existence of thousands of places in the names of Ashrams of the Maharshis like Vedvyas, Balmiki, Biswamitra, Parasar, Parshuram and many more rishis gives proofs that the great "Sanskrit Literature" was written in the present-day Nepal Himalayas. This can claim-the recorded -the "First World Order of Civilization" on earth for a cohesive society. Pity that western world recognized part of it in the name of "Indus Valley Civilization". Take the case of Samuel P. Huntington's "Political Order in Changing Society" (Huntington, 2006) and its prescription today. All political scientists know that this is limited and not a complete prescription.

In this light, great oriental thinker and practitioner of our time KapilAdwait says, "Time is bound to motion." (Adwait, 2013). Similarly, perhaps the greatest physicist today, after Einstein from 20th Century, Stephen Hawking in his book "A Brief History of Time" speaks closer to Kapil but this author did not find that he accounted time measured by the "Himalayan Civilization". From Vedic Era to -until today, some $4.2 \mathrm{~m}$ years have been passed (not only 250 years), and it contained four Yugas: Satya, Tretaa, Dwaapar and Kali with their ages. The name of this part of the Himalayas, Nepal, used to be called as Satyawati (Aryal, 2069) in Satya Yuga. In Treta Yuga, Nepal's name was Tapobhumi (Ibid) and in Dwaapar Yuga, Nepal was known as Muktiswapaan and in Kali Yuga (Panta, 2069) it came to be known as Nepal. The very time Nepal used to be also known as Himwatkhanda (Panta S. D., 2069). And the system of governance, that time, only monarchical system prevailed on this part of the globe as a cohesive society.

To come to the point of today's "Hard Power", it is said in Sanskrit, buddhiryasyabalamtasyanirbuddhestukutobalam, pasyasimhamadonmattasasakenanipaatita (Niti S.) = Knowledge is power. It is imparted from five elements of life- earth, water, air, energy and sky (panchamahaabhuta). On the glory of the Nepal Himalayas for a cohesive society, this author recalls three great thinkers, them, but not as religious persons, and they are: Maharshi Mahesh Yogi, Shivapuri Baba and Khpatad Baba. The latter two spent their later part of lives in Nepal and the former in 1975, while in Nepal, publicly said, "Nepal Led Earlier and is to Lead the World in Future". Albert Einstein mentioned about Shivapuri Baba and all four believed in science, but the latter as a Man of the $20^{\text {th }}$ Century, shifted the ancient World Order for a cohesive society of vision and practice of the East to the West, because, Kapil regards, "Science is an imparting knowledge." (Ibid), and "does not belong to any single community only." As a matter of fact, science, without laboratory, is incomplete as likely suffered by Nepalese society even today. It has to be accepted that today's evolution of science and technology is the result of the huge lab invented by the popularly known western world.

The shift of World Order for a cohesive society started from here. In Albert Einstein's words, "What I see in nature is a magnificent structure that we can comprehend only very imperfectly, and that must fill a thinking person with a feeling of 'humility'. This is a genuinely religious feeling that has nothing to do with mysticism." (www.twitter.com.einsteinBot, n.d.) In Sama Veda, it is said, udutyamjaatavedasamdevambahantiketawah, drishewisyaayasuryam (Ganapati, 1992) -means that all 
Nepal: Challenges to Create a...| 58

knowledge takes its rise to the upward direction, and consciousness moves, perceives all and bestows on the home. Perceiving this way, it compels us to realize that a vision without practice remains a vision only. Precisely speaking, that is how America became on the top of the World Order list in the modern world. But the challenge is: is this a complete cohesive society?

\section{Pre-War-Conflict-Position of the New World Order for a Cohesive Society}

The WW I had the slogan- "The War to End All Wars". The Treaty of Versailles 1919 ended WW I and established the League of Nations for world peace. The then American President Woodrow Wilson, through his popular Fourteen Points, was able to convince the "world leadership" to establish the League of Nations for a cohesive society but failed to convince his own people. The American Senate did not permit America to join the League. It later proved to be important ground of the failure of the international body.

The "Peace and Disarmament Commission" of 1925 did not oblige America practically for stopping the development of nuclear arms. Perhaps Hitler did not like that Albert Einstein migrated to the US leaving Europe. Incidentally, Germany withdrew its membership from the League the same year of 1933 -the year Einstein migrated to USA. Italy and Japan joined Hitler to withdraw from the League of Nations in 1936. It is remarkable that Albert Einstein wrote a letter to the President of the USA in 1939 appealing to take the lead of the "Strategic World Order" by developing nuclear arms. Again the very significant year relating to Einstein 1939, Hitler started WW II to establish the "Nazi World Order" contrary to a cohesive society. Perhaps if the Allied Power had not developed the superior technology in comparison to the Axis Power, the latter might have destroyed the world civilization further. The first nuclear devastation in the history of the human civilization of Hiroshima on August 6, 1945 and Nagasaki on August 9, 1945 was a landmark lead of the USA to maintain "Strategic New World Order" leaving the dominant colonial powers like UK and others far behind. It compelled Emperor Hirohito of Japan to surrender to Allied Powers/America on August 15, 1945 ending WW II. It stood both as a hope and despair for a cohesive society indeed.

Passing through such evolution of the world history in the name of a cohesive society ultimately, America again took the lead to establish the United Nations through Bretton Woods System for peace, security and prosperity of the world. The opening of the Pandora's Box was started by the Major Allied Powers of WW II. In other words, they were then Strategic Hard Powers- America, Soviet Union, UK and France wanted their largest share in the UNO in the name of Veto Power. The Veto Power meant -above all powers in fact. That's how the democracy was curtailed in the name of democracy in the World Body. This later pretended to pass Universal Declaration of Human Rights in 1948 for a cohesive society shedding the crocodile's tears.

\section{The Cold War Dilemma for New World Order and Cohesive Society}

The Soviet Union had lost $26.5 \mathrm{~m}$ people, slightly less than present-day Nepal's population. The figure really was the largest among countries they took part in war. It was a communist country. Stalin agreed to divide Germany and Korea including the City of Berlin. This city in turmoil in 1949 gave birth to the terminology of Cold War. The post- War major events were: decolonization of India and many countries in Asia and Africa together with separation of Pakistan in 1947, birth of State of Israel in 1948, Birth of Warsaw Pact and COMECON and being of Soviet Union a $2^{\text {nd }}$-nuclear power and establishment of PRC in 1949, Korean War of 1950-53, NAM 1961, Sino-Indian War of 1962, Vietnam War, Birth of Bangladesh in 1971, Merge of Sikkim into India in 1975, Falling of Berlin Wall in 1989 and Collapse of Soviet World Order challenging America in 1991. The so called unipolar world was supposed to lead to a cohesive world order indeed. 
At this juncture, the UN not only failed to create a cohesive society to prevent wars but also became a "paper tiger" dominated by P-5 led by America and the Soviet Union followed by China after joining the UN in 1971 as a new entrant to the Security Council. This era also drew a red line of New World Order for a cohesive society. It prescribed, "Any period of history evidencing a dramatic change in world political thought and balance of power system -with the ideological 'global governance' only in the sense of new collective efforts to identify, understand or address worldwide problems that go beyond the capacity of individual nation state to solve." (Wikipedia, 2018)

During post-War period, in terms of New World Order and global cohesive society, three leaders dominated the world -Mao, Gorbachev and George Bush. Mao remained idealistic, Mikhail Gorbachev was bound to internal strife of the Soviet Union and Bush dominated all and linked it to Gulf War and now has been extended to Afghanistan too. Erik A. Miller and Steve A. Yetiv found September 11, 1990 Nine-Point-Speech of President Bush as good as comparative to Woodrow Wilson from WW I and Franklin D. Roosevelt's from WW II. (Miller \&Yetiv, 2001). As a resultant stimulation, in 2001, American policy for New World Order for a global cohesive society was declared as follows:

- Checking the offensive use of force

- Promoting Collective Security

- Using Great Power cooperation. (Ibid)

Before declaring this American policy in 2001, Henry Kissinger in 1994 had observed, "The New World Order cannot happen without U.S. participation, as we are the most significant single component. Yes, there will be a New World Order, and it will force the United States to change its perceptions." (Ibid). Was Henry Kissinger correct in his assessment for a cohesive society? The chapters ahead, with data analysis, will give the answer.

\section{Hard Power Status of the Strategic Order Hampering a Cohesive Society in Countries like Nepal and More}

This chapter deals with the available data on the capacity of the World Nuclear Forces 2014. Like in WWII, any wars or say WW III, in Hard Power terms, not for "water" but nuclear or chemical wars will be decisive. Tables below show the status and arms spending as enemy to a cohesive society.

Table 1: World Nuclear Forces 2014

\begin{tabular}{|c|l|c|c|c|}
\hline S. N. & Country & Deployed Warheads & Other Warheads & Total Inventory \\
\hline 1. & USA & 2100 & 5200 & 7300 \\
\hline 2. & Russia & 1600 & 6400 & 8000 \\
\hline 3. & UK & 160 & 65 & 225 \\
\hline 4. & France & 290 & 10 & 300 \\
\hline 5. & China & - & 250 & 250 \\
\hline 6. & India & - & $90-100$ & $90-100$ \\
\hline 7. & Pakistan & - & $100-120$ & $100-120$ \\
\hline 8. & Israel & - & 80 & 80 \\
\hline 9. & DPRK & - & $6-8$ & $6-8$ \\
\hline Total & 9 & 4150 & 12200 & 16350 \\
\hline
\end{tabular}

Source: SIPRI Year Book as of January 2014 
Among P-5 in the UN Security Council; USA, Russia, UK and France have the Nuclear Warheads deployment. The data does not show rumored Iran and South Africa in the list. The DPRK provocation also does not seem very high in comparison to other 8 nuke-powers but latest ICBM Tests up to 2017 might lead Pyongyang to a nuclear nation despite US threat. These states have not signed CTBT also. Since 1945 to 2013, the 8-States USA, then Soviet Union, UK, France, China, India, Pakistan and North Korea had 2055 known explosions. The range of the size varied 5-16 Kilotons (Stockholm International Peace Research Institute, 2014). The nuclear powers are the greatest threats to the cohesive societies ultimately.

Table 2: World Military Expenditure 2013

\begin{tabular}{|c|l|c|c|}
\hline S. N. & Different Regions & Spending in US \$ in billion & Percentage Change \\
\hline 1. & Africa & 44.96 & 8.3 \\
\hline 2. & Americas & 736 & -6.8 \\
\hline 3. & Asia \& Oceana & 407 & 3.6 \\
\hline 4. & Europe & 410 & -0.7 \\
\hline 5. & Middle East & 150 & 4.0 \\
\hline Total & World & 1747 & -1.3 \\
\hline
\end{tabular}

Source: SIPRI Year Book 2014

If separated from the main region to the specific, North America typically spends US \$659bn, Asia and Oceana spends US \$407bn and the West and Central Europe alone spends US \$312bn. Percentage change denote in comparison to 2012 range. The sum-up comes that the World Military Expenditure for 2013 with special significance stood US \$ 1714bn (Ibid). To relate to the Shifting World Order for a global cohesive society Impact in Nepal, it is relevant to compare The ADB Report 2014 on Nepal (Domènech, at al. 2013), which mentioned that Nepal needs US \$18-20bn but now it is estimated to be $\$ 30-35$ bn to graduate from LDC to a Developing Country Category. The NPC estimation of US $\$ 100 \mathrm{bn}$, in this regard, seems without research (National Planning Commission Nepal, 2017). Thus, the reader can automatically assess the trend of the Shift of the World Order for a cohesive society in this regard.

Table 3: Power Underwater: The Flagship Vessels of Nations with n-Missiles Hampering Cohesive Society with Detrimental Effects to Nepal

\begin{tabular}{|l|c|l|c|l|}
\hline Country/ Class: Hard Powers & Length in feet & Crew & Number/Missiles & Range \\
\hline USA/OHIO : $1^{\text {st }}$ in 1981 & 561 & 155 & $24 /$ Trident & 7000 \\
\hline Russia/DELTA-IV $1^{\text {st }}$ in 1985 & 548 & 130 & $16 /$ Seneva & 7100 \\
\hline UK/VANGUARD $1^{\text {st }}$ in 1993 & 492 & 135 & $16 /$ Trident & 7000 \\
\hline France/TRIOMPHANT: 1997 & 453 & 111 & $16 / \mathrm{M}-51$ & 5000 \\
\hline China/094JIN: $1^{\text {st }}$ in 2010 & 443 & 120 & $12 / \mathrm{JL}-2$ & 4600 \\
\hline India/ARIHANT:2015(expect) & 367 & 95 & $12 /$ Sagarika & 435 \\
\hline
\end{tabular}

Source: The Wall Street Journal, November 3, 2014

The ranges are marked in miles. India's vessels were targeted to be completed in 2015 and succeeded. Among 9 n-powers, the countries able to have vessels with n-missiles are only five. Pakistan, North Korea and Israel have not been able to deploy it effectively so far. 
61 | Journal of APF Command and Staff College

On the basis of the above data as Hard Powers, Russia is slightly higher than the USA in Underwater Power category. Also as per Table-I, Russia's n-Warheads count 8000 but USA possesses 7300 only. Here, Kissinger's statement that USA as Number One Strategic Power is not proved. It's good news for a cohesive society even for Nepal.

\section{Latest Shift in the Technology Transfer with a Counter Balance to Develop a Cohesive Society also in Nepal at a Regional Perspective}

It is very significant that in the $1^{\text {st }}$ week of November, 2014, China brought out the news that she has been able to develop Laser Cannons to shoot down the drones within a 1.2 miles radius target designed by 'China Academy of Engineering Physics'. It can shoot down the drones with 112mph anywhere below 16000.00 feet in 5 seconds. It is significant development in relation to human security for a cohesive society, because, US already relies heavily on drones (unmanned military) that fire rockets at people in Yemen, Pakistan and the Islamic State. Also that US Navy has plans in place for swarms of drone boats. Recently, the "China in the News" adds that China's Submarines add n-strikes capability (Pagliery, 2014).

\section{The Soft Power Perspective for a Cohesive Society Useful for Nepal}

China's standing as the world's $2^{\text {nd }}$ largest economy today is a great shift in Soft Power World Order helping to create an economically sound cohesive society. The PRC has easily surpassed the long ruling another Asian Giant -Japan, standing as $2^{\text {nd }}$ largest economy of the world for many decades. China grew her economy in such a way that she graciously had to play a great role to save the Great EU Recession in 2012-2013 (www.europeanrecession.com). And support at EQ2015 and promise of $\$ 8.3 \mathrm{bn}$ for the Him Rail and \$8bn for the infrastructure development. The pace of development in developing countries was a great paradigm shift for rapid economic growths in countries like China and India. Nepal's big neighbors, China and India, two largest populations of the world today, stand as the fastest growing economies of the world too and which is exemplary for Nepal's new Federal Structures with ethnic conflicts for diminishing the challenges in creating a cohesive society.

Table 4: Countries Having Super-Rapid Growth Episodes Exemplary to Nepal's Cohesive Society

\begin{tabular}{|l|c|c|}
\hline Rapid Growth Countries By Name & Duration of Exemplary Growth & Percentage \\
\hline Japan & $1960-1970$ & 9 \\
\hline Singapore & $1967-1980$ & 8 \\
\hline China & $1990-2010$ & 8.8 \\
\hline Angola & $2001-2010$ & 9.2 \\
\hline Greece & $1960-1973$ & 6.8 \\
\hline Taiwan & $1973-1975$ & 7 \\
\hline Korea & $1962-1983$ & 6.5 \\
\hline Chile & $1986-1997$ & 6.1 \\
\hline Columbia & $1996-2010$ & 6.1 \\
\hline Sierra Leone & $1999-2010$ & 6 \\
\hline
\end{tabular}

Source: Summers and Prichett 2014

Larry Summers (twitter.com) explains in detail on why the world is too optimistic about China's (xinhuanews.com) economic future. India's new regime of BJP led by Modi had also targeted 7+ percent growth in the 2014-2015 fiscal and achieved in 2016 but 2017 stranded at nearly $6.5 \%$ only. 
Nepal: Challenges to Create a...| 62

Jake Spring (reuters.com) writes in Reuters on 29 October 2014 that World Bank urges for, and forecasted, on China's growth rate to make/be 7\% in 2015 but China satisfied in $6.9 \%$ in 2017. China had targeted her growth rate to be $7.5 \%$ for 2014 . But the IMF appealed also went to China to target $6.5 \%$ to $7 \%$ for the year 2015. In response to the proposals from the world bodies, the Chinese President Xi Jinping had politely replied -not to worry for the Chinese economy, because, China is able to maintain her economy well (chinainnews.com). The regional economic stability can be supportive to Nepal's economy which directly leads to a cohesive society.

\section{The "Tug of War" Between USA and China to Maintain Economic World Order Resulting to Security and Cohesive Society in Smaller Countries like Nepal}

The detrimental effects of the uni-and multi-polar-world at post-Cold War Era are still the hangovers of pre-1991 period of socialism vs. capitalism. This author recalls the interview with James Rosenau of George Washington University in late 1990's that whether this post-1991 world runs as per national interest or ideology, he had told, "The world still runs as per ideology (Nepal, 2003). After EU embargo to Russian Federation, Putin started to supply meat to China after signing the historic energy pact of US \$70bn with Xi Jinping in Beijing and he also started to prepare Russia to defend the EU and G8 pressure over Ukraine. One interesting news coverage appeared at "China in the News" (chinainthenews.com) entitled, "Putin Tiger Crosses into China"-promoting diplomatic rush for meat and energy!

Mark Gongloff in The Huffington Post wrote, "China Now Has the World's Biggest Economy" (thehuffingtonpost.com). The calculations were based on the GDP. The data for then China's GDP was given as US \$17.6 trillion. It has adjusted for China's relatively low cost of living compared with then US \$17.4 trillion. The IMF estimated as part of its latest World Economic Outlook as of 2018, China's is estimated to of US \$25 trillion and USA of 21 trillion. The GDP calculation is based on the popular methodology of PPP- Purchasing Power Parity.

China's Global Share of the Global Economy is now slightly bigger than America's. The US holds $16.3 \%$ share of the Global Economy whereas China holds it as $16.5 \%$ - a neck to neck competition. The per capita income on the basis of purchasing power is regarded as base of ranking. But China seems still dwarf if calculated the per capita income as per present US market basis. For instance, the GDP breaks down to US $\$ 55000.00$ per capita per year in the US compared with less than US $\$ 8000.00$ per person in China. It is estimated that USA will hold US \$65000.00 and China US \$10 000.00 per person by 2018 (www.chinainthenews.com).

The economists argue that if the GDP is calculated in the current prices, the GDP in terms of sheer size, however, meaning not adjusted for the costs of living, the Chinese economy still dwarfs the US of \$17.4 trillion to US \$10.4 trillion. Dr. Rosita Dellious also gives justifications on "The Rise of China as a Global Soft Power (Dellious, 2004). The Guardian has brought out scholarly article accepting that the "Soft Power" is a key asset in the new international order (softpower.com).

In one hand, Xi Jinping demanded agreement with Barrack Obama for more US FDI in China, and on the other, the latest situation dealing with Donald Trump is that the Chinese investment patterns are shifted from China to outside due to slow growth suggested by World Bank for $7 \%$ growth to a member country of WTO in 2001. SameilAndelini, in Financial Times, writes that looking at doing business in China, "the Chinese are now the biggest purchasers of expensive properties in London, New York and Sydney and the Chinese investors are buying everything from the Italian utility co's to the Waldorf Astonia Hotel in New York City (reports/@ftreports.com). That is an effort pertaining to a cohesive society. 
63 | Journal of APF Command and Staff College

Alibaba's US \$25bn share sale made Jack Ma, the richest man of China. It is exemplary in the capitalism from a socialist market economy that Alibaba shares ended their first trading day up nearly $40 \%$ and the company was valued at more than Facebook, Amazon, JPMorgan or Procter and Gamble. Since the growth rate is supposed to be controlled in China, many Chinese Co's are looking abroad to make investments, enter foreign markets and acquire valuable technology and brands until today (reports/@ftreports.com).

It is natural that two Economic Super Powers are in the "tug of war" to sustain the Economic World Order which ultimately tends to a global cohesive society. On 24 October 2014, on the 69th Birthday of the UN, China signed agreement to establish International Development Bank known as "Asian Infrastructure Investment Bank" with total capacity of US $\$ 50.00 \mathrm{bn}$ (now $\$ 100 \mathrm{bn}+$ ) proposed in 2013 to begin. It has been signed by important economic powers of the region including Nepal. But USA, World Bank, Asian Development Bank have/had different view. They had registered the opinion that it would undercut the role of the World Bank. That is why it is not hidden that USA indirectly tried to block its allies to participate in AIIB to be as the founder signatories. As a result, the countries working under the American Umbrella like Japan, South Korea, Australia and Indonesia did not participate in the Beijing International Development Bank signing meeting on October 24, 2014 (www.chinainthenews.com). But now they had to change their viewpoints in conformity for a cohesive society.

Then Chinese Finance Minister Low Jiwei had clarified that World Bank and ADB are for poverty reduction but AIIB is for infrastructure development. But World Bank President Takehiko Nakao was in contrary to the view of the Chinese Finance Minister. Similarly at the beginning, ADB also was not happy with the AIIB and had strongly put the view that ADB already in 2009 had estimation of US $\$ 8$ trillion for the infrastructure development of the region (ChinaInTheNews.com). It is open secret that the establishment of BRICS (brics.com) as well is not welcome to World Bank, IMF, ADB, EU and NATO -all in US virtual command having negative impact for a cohesive society.

On 3 November 2014, Bob Davis admits in The Wall Street Journal, "US Blocks China Efforts to Promote Asia Trade Pact at Free Trade Zone at Asia Pacific (Davis, 2014). Here is the ground why important countries like South Korea, Japan, Indonesia, etc. at the beginning, hesitated to join the signing ceremony of the 20-countries pact of establishing International Development Bank in Beijing.

Naturally, Japan also finds China overtaking its $2^{\text {nd }}$ position. But power cannot be avoided, because, "Chinese Smart Phones Lift Japan's Electronic Business". To cite the upstart Chinese phone makers like XiaomiInc, Lenovo Group Ltd. and Huwai Technologies Co. etc. are increasingly undercutting smart phone giants like Apple Inc, and Samsung -Electronic Co. with and other problems! Similarly, "Him Rail Network", connecting India and China via Nepal, due to their bilateral security paradigms, is the best option of land route creating cohesive societies through stable economy (Nepal, 2014). Otherwise the option is open to appeal EU, Japan- the $3^{\text {rd }}$ largest economy (Nepal, 2004), and ASEAN for the necessary FDI. Certainly both, the investors and the receivers, will benefit from the strategic location and potentials of Nepal and SAARC for a cohesive society.

\section{Conclusion}

On domestic fronts, Nepal can imply 4T-HEI Model (Nepal, 2004) for economic development, PCDRS Model (Nepal, 2003) for conflict resolutions, 4S Model (Nepal, 2013) for state restructuring and finally forward Regional Navigation Paradigms of Foreign Policy as passed by Nepal Parliament in 2068 VS to mitigate the detrimental effects of restructuring the state for a cohesive society. 


\section{References}

Adwait, K. (2013). Himalaya KahaRahaHai Part I \& II. Kathmandu: Pilot Baba World Peace Foundation.

Aryal, R. P. (2069). Nepal Kolitihas.

Aryal, R. P. (2069). Nepal KoItiahas.

Bidwai, P. (2006). Changing the Mirage of Nuclear Stabilisation: Security and Nuclear Stabilization in South Asia,(pp. 43-66). Sapana, Lahore.

China In The News. Retrieved from @ChinaInTheNews bit.ly/1uQelWa

Davis, B. (2014, November). The Wall Street Journal. Retrieved from www.TheWallStreetJournal.com

Dellious, D. R. (2004). "The Rise of China as A Global Soft Power”, The Culture Mandala, (No 2).

Dolven, B., Elsea, J. K., Lawrence, S. V., O’Rourke, R., \& Rinehart, I. E. (2015). Chinese Land Reclamation in the South China Sea: Implications and Policy Options: Current Politics and Economics of Northern and Western Asia, 24 (2/3), 319.

Dolven, Domènech, L., March, H., \&Saurí, D. (2013).Contesting Large-scale Water Supply Projects at Both Ends of the Pipe in Kathmandu and Melamchi Valleys, Nepal. Geoforum, 47, 22-31.

Ganapati, S. V. (1992). Sama Veda, Agneya Kanda. New Delhi: MotilalBanarasidas.

Hachhetu, K. (2006). Nepal Confort its Hindu Identity (Vol. ix). SAPANA, Lahore.

How Can SAARC Work?”, SAARC, South Asian Studies. (2006). SAPANA, Lahore, Vol. 13, x-xv.

Huntington, S. P. (2006). Political Change Societies.

Indian Express. (2014, November 12). Retrieved February 13, 2018, from http://epaper.indianexpress.com/373305/Indian-Express/12-November-2014\#page/28/1

Miller, E. A. \&Yetiv, S. A. (2001). The new world order in theory and practice: the Bush administration's worldview in transition. Presidential Studies Quarterly, 31(1), 56-68.

NagarjunraUnkoShunnyawaad.In A. A. Darshan.OshoTapowan.

Nath, Y. N. (2049). AitihaasikShikharniYatra. Kathmandu: Shree BagiswariAdhyatmikParisad.

National Planning Commission Nepal. (2017). National Planning Commission Forecasting in the International Community, Kathmandu: NPC.

Nepal Parliament.(2068 B.S.).ParivartitSandharbamaNepalkoBideshNiti -2068.Singhadarbar, Kathmandu.

Nepal, B. H. (2003). , UN Peacekeeping in post-Cold War Era: Third World Perspectives, B.H.U., p. $1-289$.

Nepal, B. H. (2004). “Nepal-Japan: Warmth of Friendship.” TODAY, 23(5), 15-18.

Nepal, B. H. (2004). Need of New Thrust in Nepal India Relation.Inter state Conflict In South Asia, . New Delhi: SAFMA, NEW Delhi Declaration.

Nepal, B. H. (2005). Inundation Tragedy.South Asian Journal, 8, 50-51.

Nepal, B. H. (2005). Nepal-Japan: Warmth of Friendship. Today, 23, 15-18. 
65 | Journal of APF Command and Staff College

Nepal, B. H. (2006). Managing South Asia's Water (Nepal's National Water Plan and Regional Issues: SA-RRR-S Model: Demand of Time for South Asia), pp. 62-84.

Nepal, B. H. (2009). Nepal Japan Relation., (p. na). Kathmandu, Nepal.

Nepal, B. H. (2011). Reaching the Unreachable. Retrieved from Daily Sun: http://www.com.dailysun

Nepal, B. H. (2014). Asia Pasific Daily (Detrimental Effects of Opening Nathula Pass), 2.

Nepal, B. H. (2014). China, Nepal, India and SAARC Need Strong Strategic Partnership: The Relevance of Xi Jinping Doctrines. TODAY, 32(7), 13-40.

Nepal, B. H. (2014, November 12). Twitter. Retrieved February 13, 2018, from http://www.com.twitter.drbishnuhnepal

Nepal. (2014). Point for Modi to Reconsider. 6.19.

Nepal's Foreign Policy.Nepal Parliament. 2068.

Pagliery, J. (2014). China claims new laser cannon shoots down drones. CNN Tech, published on Nov.3. Retrieved from 25/2/2018.

https://scholar.google.com/scholar?hl=en\&as_sdt=0\%2C5\&q=http\%3A\%2F\%2Fmoney.cnn. com\%2F2014\%2F11\%2F03\%2Ftechnology\%2Fsecurity\%2Fchina-laserdrone $\% 2$ Findex.html\&btnG $=$

Panta, S. D. (2069). VeidicRaajdharamaraPurviyaSasanVyawasthaa. Kathmandu: SIRUD.

Parliament of Nepal (2068 BS). Nepal's Foreign Policy . Border Diplomacy , 6.10, p. 34.

Ramesh, J. (2008). SAARC and Connectivity. (D. Banerjee, Ed.) SAARC Towards Greater Connectivity, 22 (KAS), 24-36.

Rig-Veda, Sama Veda, Yajur Veda and Atharva Veda.

Stockholm International Peace Research Institute. (2014). SIPRI Yearbook 2014: Armaments, Disarmament and International Security. Oxford University Press.

Subedi, C. P. (2063). In Kathmandu (pp. 1-250).ChausatthiJyotirlingaVarnan, Chitra Prasad SewaGuthi.

Thapa, S. (2010). Buddhism: The Icon of Cultural Linkage with China. pp. 1-446.

UNESCO. (2013).

Wikipedia.(2018, Jan).Wikipedia.Retrieved January, 2018, from https.//en.wikipedia.org/wiki/ Global 